\title{
Molecular Study of Vancomycin Resistance in Hospital Acquired Staphylococcus Infection
}

\author{
Maysaa El-Sayed Zaki ${ }^{1}$, Aalaa Abouelnour ${ }^{2}$, Sherif MH El-Kannishy ${ }^{3 *}$ and Rasha Hassan ${ }^{4}$ \\ ${ }^{1}$ Department of Clinical Pathology, Faculty of Medicine, Mansoura, Egypt \\ ${ }^{2}$ Department of Toxicology, Mansoura Hospital, Mansoura University, Mansoura, Egypt \\ ${ }^{3}$ Department of Pharmacology and Toxicology, Faculty of Pharmacy, University of Tabuk, Tabuk, Saudi Arabia \\ ${ }^{4}$ Department of Medical Microbiology, Faculty of Medicine, Mansoura, Egypt \\ *Corresponding author: Sherif MH El-Kannishy, Department of Pharmacology and Toxicology, Faculty of Pharmacy, University of Tabuk, Tabuk, 71491, Saudi \\ Arabia, E-mail: aalaa_abo@yahoo.com
}

Received July 18, 2019; Accepted August 10, 2019; Published August 19, 2019

\begin{abstract}
Purpose: Vancomycin is treatment of choice in MRSA infection. In the last years there is increasing incidence of vancomycin resistance either vancomycin intermediate $S$. aureus (VISA) or vancomycin-resistant staphylococci (VRSA). This increasing in resistance strains is challenging problem especially in hospital acquired infection. The present study was carried out to find the incidence of(VISA)and(VRSA) among MRSA in children hospital in Egypt with correlation of molecular study for mec A gene and Vancomycin resistance gene Van A, Van B and Van C genes by multiplex PCR.
\end{abstract}

Method: Out of 678 hospital acquired infection (365) staphylococcal isolates was obtained in which coagulase negative were (152) (41.6\%) and positive (213) (58.4\%) were isolated from various samples which confirmed to be hospital acquired infection according to CDC guidelines.

All Staphylococcal aureus isolates and coagulase negative (CoNS) were suspected to antibiotic disc diffusion. MRSA strain were subjected to MIC for vancomycine and molecular study for detection mec A and Van A, Van B and Van C genes by multiplex PCR

Results: MRSA was reported in (103) staphylococcal and (10) CONS mec gene was present in all MRSA stain. Vancomycine resistance gene was not found in any of CoNS. While in staphylococcal aureus vanA was present in 2 VRSA and 4 VISA isolates and van B was present in 6 VISA and in one VRSA isolates vanC gene was not found either in Staphylococcus aureusnor CoNS.

Conclusion: The results of the current study illustrate the emergence of vancomycin resistance among methicillin-resistant $S$. aureus isolated from children with healthcare-associated infections. The majority revealed the occurrence of vanA and vanB as an accountable mechanism for this resistance.

Keywords: MRSA; Multiplex PCR; Van A; Van B; Vancomycin resistance.

\section{Introduction}

Staphylococcus is a major pathogen in hospital acquired infections. It has variety of virulence factors and capable of acquiring resistance to most of antibiotics making $S$. aureus a "superbug. In the last decade, methicillin resistant $S$. aureus (MRSA) strains have become endemic in hospitals worldwide [1]. MRSA is difficult in treatment because it is resistant to methicillin as well as to other $\beta$-lactam antibiotic, with the exception of glycopeptides antibiotics [2,3] Vancomycin as glycopeptides $\backslash$ have been used as a therapeutic alternative for the treatment of MRSA [4], but due its excessive use resistant strains have been reported to reemerge among $S$. aureus species. The mechanism of vancomycin resistance in $S$. aureus is not fully known. It is may be due to association of Vancomycin-resistant genes with $S$. aureus species. These genes are seven types of resistance genes namely (van A, B, C, D, E, G, and L) which are usually transferred by transposon Tn1546 [5].

The aim of the present study was to identify the emergence of vancomycin-resistant $S$. aureus among MRSA resistant strains and to identify the occurrence of van $A, \operatorname{van} B$ and van $C$ genes among resistant isolates.

\section{Material and Methods \\ Isolates}

The study was conducted at Mansoura University Children hospital, Egypt from December 2014 till March 2017. The study included isolated S. aureus strains from children diagnosed to have health care associated infections (HCAI) according to CDC [4]. The patients signed written consents and the study was approved by Mansoura Faculty of Medicine ethical committee. The strains were from variety of hospital acquired infection including pus blood sputum catheters swabs and urine

\section{CULRUER}

Blood agar and Macconkey agar were used for samples except for urine samples which were inoculated on CLED the samples were incubated for $24-48 \mathrm{~h}$ at $37 \mathrm{C}$.

\section{Identification of Staphylococci}

The included samples were from various clinical samples such as blood, pus and body fluids. The isolates were identified as $S$. aureus by standard biochemical techniques and conventional methods (colony morphology, Gram stain, catalase activity, and slide and tube coagulase test) after primary culture of the clinical samples.

\section{Antibiotics susceptibility test by disc diffusion}

Antibiotics susceptibility was performed by agar disc diffusion method with the use of the following discs: Vancomycin $(30 \mu \mathrm{g})$, Erythromycin (15 $\mu \mathrm{g})$, Ampicillin/Sulbactam $(20 \mu \mathrm{g} / 20 \mu \mathrm{g})$, Amoxicillin/cavulanic $(20 \mu \mathrm{g} / 10 \mu \mathrm{g})$, Pipracillin $(30 \mu \mathrm{g})$, ciprofloxacin $(5 \mu \mathrm{g}) /$, Ceftriaxone $(5 \mu \mathrm{g})$, Cephradine $(30 \mu \mathrm{g})$, Cefotaxime $(30$ $\mu \mathrm{g})$, Clindamycin $(2 \mu \mathrm{g})$, Ceftazidime $(30 \mu \mathrm{g})$, Cefoperazone $(75 \mu \mathrm{g})$, (Oxoid-England).

\section{MRSA detection}

Determination MRSA isolates was reported as those strains with inhibition zone $\leq 21 \mathrm{~mm}$. and for CONS $\leq 24 \mathrm{~mm}$ for (cefoxitin) [6-16]. 


\section{Minimal Inhibitory Concentrations (MICs) for vancomycin}

The determination of minimal inhibitory concentrations (MICs) for vancomycin was performed by the use of standardized agar dilution techniques. Briefly, gradient plates of Mueller-Hinton agar of vancomycin $(0.5-128 \mu \mathrm{g} / \mathrm{ml})$. With direct colony suspension method $0.5 \mathrm{McFarland}$ equivalent inoculums were prepared in normal saline from $18-24 \mathrm{~h}$ agar plate culture. The suspension then was diluted to achieve needed inoculum concentration. All strains were placed into gradient plates. Plates were incubated overnight at $35^{\circ} \mathrm{C}$ for any visible growth. Readings were taken according to NCCLS guidelines [17-20]. S. aureus ATCC 29213 and Enterococcus faecalis ATCC 29212 strains were used as vancomycin sceptible controls and E. faecalis ATCC 51299 as vancomycin resistant control.

Vancomycin resistance among MRSA according to MIC was classified into susceptible, intermediate susceptible and resistant according to CLSI, 2009 [10].

\section{Detection of mecA gene by PCR}

\section{DNA preparation}

One colony of pure culture was suspended in $25 \mu \mathrm{L}$ of sterile water and the suspension was put in the water bath at $100^{\circ} \mathrm{C}$ for 12 minutes. One micron of the suspension was used for PCR amplification. The oligonucleotide primers for mecA gene (mecA F 5'GTAGAAATGACTGAACGTCCGATGA $3^{\prime}$ and mecA R 5CCAATTCCACATTGTTTCGGTCTAA 3')

A Biometra DNA thermocycler was programmed with the initial denaturation, $4 \mathrm{~min}$ at $94^{\circ} \mathrm{C} ; 30$ cycles with a 45 -s denaturation step at $94^{\circ} \mathrm{C}$, a 45 -s annealing step at $56^{\circ} \mathrm{C}$ and a 30 -s extension step at $72^{\circ} \mathrm{C}$ and 2 min extension step at $72^{\circ} \mathrm{Cand}$ a holding step at $4^{\circ} \mathrm{C}$ until the sample was analyzed. After amplification $10 \mu \mathrm{L}$ of the reaction mixture was loaded into a $1 \%$ agarose gel stained with $10 \mu \mathrm{L}$ ethidium bromide and electrophoreses to estimate the sizes of the amplification products with a 100-bp molecular size standard ladder (Sigma). The positive tests have shown PCR product of $310 \mathrm{bp}$. Sterile distilled water was used as a negative control under complete sterile standard precautions for PCR. S. aureus ATCC 29213 reference strain was used as mecA positive control strain.

\section{Multiplex PCR for Van A, B, C genes}

\section{DNA preparation}

One colony of pure culture was suspended in $25 \mu \mathrm{L}$ of sterile water and the suspension was put in the water bath at $100^{\circ} \mathrm{C}$ for 12 minutes. One micron of the suspension was used for PCR amplification [17].

\section{Multiplex PCR}

The primers sequences used in PCR and amplification were as follow, vanA 5'-ATG AAT AGA ATA AAA GTT GC-'3, 5'-TCA CCC CTT TAA CGC TAA TA-'3 bp1032 [7], vanB 5'-GTG ACA AAC CGG AGG CGA GGA-'3, 5'-CCG CCA TCC TCC TGC AAA AAA-'3, 430bp [8], vanC 5'-ACG AGA AAG ACA ACA GGA AGA CC-3, 5/-ACA TCG TGA TCG CTA AAA GGA GC-'3, 815bp [9]. The multiplex PCR was performed according to Perez-Roth et al. [6] by the use of Qiagen amplification kit. After amplification $10 \mu \mathrm{L}$ of the reaction mixture was loaded onto a $1 \%$ agarose gel stained with $10 \mu \mathrm{L}$ ethidium bromide and electrophoreses to estimate the sizes of the amplification products with a 100-bp molecular size standard ladder (Sigma),. Enterococcus faecalis ATCC 29212 were used as van A/B/C negative control strain

\section{Results}

Out of 678 hospital acquired infection isolates (365) isolates were staphylococcal in which CONS (coagulase negative) were (152) (41.6\%) and positive were (213) (58.4\%) The isolated were from various clinical samples which confirmed to be hospital acquired infection according to CDC guidelines.

Resistance to cefoxitin representing MRSA was reported in 113 (30.9\%) mostly in coagulase positive (103) isolate sand [10] isolates coagulase negative (CoNS). Isolated MRSA species were all resistant to most of the commonly used antibiotic cefoxitin and amoxicillin/ clavulanic with high resistance to ampicillin/sulbactam (94.7\%), clindamycin and erythromycin (85.7\%), vancomycin (17.6\%).

Vancomycin resistance among MRSA was classified according to MIC into susceptible, intermediate and resistant according to CLSI. Two isolates of Stap. Epidermides show VISA pattern with MIC $8 \mu \mathrm{g} / \mathrm{ml}$ and $4 \mu \mathrm{g} / \mathrm{ml}$. In Staph. Aureus VISA was found in thirteen (12.6\%) isolates with MIC 4-8 $\mu \mathrm{g} / \mathrm{ml}$ VRSA was reported in five isolates. mec A gene was present in all MRSA strain. In CoNS vancomycin resistance gene was not detected while in Staph. aureus van A gene was detected among four isolates with intermediate susceptibility and in two resistant strains. van $B$ was more commonly associated with intermediate resistance pattern in six isolates and in one resistant strains and none of the isolates had van $C$ (Table 1).

\section{Discussion}

Hospital acquired infection caused by resistance stains represents real challenge to heath care system [1]. This study reported the presence of MRSA in (30.9\%) among HAIs in children hospital during the period of the study. Where Staphylococcus aureus (28.2\%) and CoNS was $(2.7 \%)$. Similar rates were reported in studies done in developing countries [12], while lower rates were reported in developed countries such as USA [21,22].

Our findings demonstrated high resistance of MRSA to mostly common used beta-lactams and macrolides antibiotics with rates from $85 \%$ up to $100 \%$. These high rates of resistance are also reported from other studies $[14,15]$. The high rate of resistance could be explained that in developing countries like ours there is irrational use of antibiotic due to its availability at the drug store without prescription also uncontrolled use in hospitals and uncontrolled use in agriculture, animal industry and fisheries [5], As the infection by MRSA consider a strong risk factor to vancomycin resistance and vancomycin resistance was not reported from methicillin-susceptible strain [22].

This goes with our pattern of MIC to vancomycin as there is resistance to vancomycin only in MRSA and not in MISSA strain. Also our result shows that VISA pattern was present in two CONS stain and thirteen staph. Auras, and VRSA pattern was present in five isolates of Staphylococcus aureus not present in CONS

The two strains of CoNS (Staphylococcus epidermis清: One with

\begin{tabular}{|c|c|c|c|}
\hline Genes & $\begin{array}{c}\text { Cons } \\
\mathbf{N = 1 0}\end{array}$ & $\begin{array}{c}\text { VISA in } \\
\text { Staphylococcus } \\
\text { aureus N=13 }\end{array}$ & $\begin{array}{c}\text { VRSA in } \\
\text { Staphylococcus } \\
\text { aureus N=5 }\end{array}$ \\
\hline MEC A & 2 & 13 & 5 \\
\hline Van A & - & 4 & 2 \\
\hline Van B & - & 6 & 1 \\
\hline Van C & - & - & - \\
\hline
\end{tabular}

Table 1: Molecular study of mec A gene and van gene in VRES and VISA isolates. 


\begin{tabular}{|c|c|c|c|c|c|c|c|c|c|c|}
\hline S. N o & Strain (MRSA) & $\begin{array}{c}\text { No. of } \\
\text { isolates }\end{array}$ & $\begin{array}{c}\text { MIC of } \\
\text { Vancomycin }\end{array}$ & Sample & $\begin{array}{c}\text { History vancomycin } \\
\text { use in past 30 days }\end{array}$ & $\begin{array}{c}\text { Primary } \\
\text { Illness }\end{array}$ & $\begin{array}{c}\text { Durat-ion of } \\
\text { hospital stay }\end{array}$ & Age & PCR OF VAN PCR OF MEC \\
\hline 1 & S. aureus & 11 & 64 & Blood & Yes & Renal failure & $12 \mathrm{~d}$ & $13 \mathrm{y}$ & Van A & Positive \\
\hline 2 & S. aureus & 27 & 16 & Blood & Yes & $\begin{array}{c}\text { Cardiac } \\
\text { diseases }\end{array}$ & $10 \mathrm{~d}$ & $4 \mathrm{y}$ & Yes & Positive \\
\hline 3 & S. aureus & 15 & 16 & Pus & Not recorded & $\begin{array}{c}\text { Respiratory } \\
\text { diseases }\end{array}$ & $6 \mathrm{~d}$ & $9 \mathrm{~m}$ & No & Positive \\
\hline 4 & S. aureus & 22 & 32 & Pus & Yes & Leukemia & $6 \mathrm{~d}$ & $5 \mathrm{y}$ & $\begin{array}{c}\text { Van A } \\
\text { Van B }\end{array}$ & Positive \\
\hline 5 & S. aureus & 5 & 8 & Blood & Yes & $\begin{array}{c}\text { CNS } \\
\text { Anomalies }\end{array}$ & $10 \mathrm{~d}$ & $4 \mathrm{y}$ & No & Positive \\
\hline 6 & S. aureus epidermidis & 78 & 4 & Aspirate & Yes & $\begin{array}{c}\text { Renal } \\
\text { diseases }\end{array}$ & $10 \mathrm{~d}$ & $9 \mathrm{y}$ & No & Positive \\
\hline 7 & S. epidermidis & 91 & 8 & Blood & Yes & Leukemia & $15 \mathrm{~d}$ & $5 \mathrm{y}$ & No & Positive \\
\hline 8 & S. epidermidis & 9 & 4 & Blood & Not recorded & $\begin{array}{c}\text { Cardiac } \\
\text { diseases }\end{array}$ & $10 \mathrm{~d}$ & $9 \mathrm{~m}$ & No & Positive \\
\hline 9 & S. epidermidis & 36 & 4 & Blood & Not recorded & GIT & $7 \mathrm{~d}$ & $8 \mathrm{y}$ & No & Positive \\
\hline
\end{tabular}

Table 2: The data of the VISA and VRSA is shown in relation to the detection of mec gene and van gene and clinical history.

\begin{tabular}{|c|c|c|c|c|c|c|c|c|c|}
\hline Guidelines & $P(11)$ & $\mathbf{P}(27)$ & $P(15)$ & $P(32)$ & $P(5)$ & $P(78)$ & $P(91)$ & $P(9)$ & $P(36)$ \\
\hline Private Room & 0 & 1 & 1 & 0 & 0 & 0 & 0 & 0 & 0 \\
\hline Gloves & 1 & 0 & 1 & 0 & 1 & 1 & 0 & 0 & 0 \\
\hline Gown to Enter Room & 1 & 0 & 1 & & 1 & 1 & 0 & 0 & 0 \\
\hline Antibacterial Hand Washing Agent & 0 & 0 & 1 & 0 & 1 & 1 & 0 & 0 & 1 \\
\hline Recording Health Care Working Entering Room & 0 & 0 & 0 & 0 & 0 & 1 & 0 & 0 & 0 \\
\hline Limit Number of Heath Care Worker & 0 & 0 & 1 & 0 & 0 & 0 & 0 & 0 & 0 \\
\hline
\end{tabular}

Table 3: Infection control guidelines for vancomycin-resistant Staphylococci.

vancomycin $8 \mu \mathrm{g} / \mathrm{ml}$ was isolated from urine specimen of patient (10years old) who was admitted in renal ward, and the other with vancomycin $4 \mu \mathrm{g} / \mathrm{ml}$ was isolated blood of patient (6years old) who was admitted to intensive care unit. The vancomycin resistance in CoNS either VRSA or VISA have been reported in other hospital as in Brazil which reported vancomycin resistant strains of CoNS [9]. And in India also reported the emergence of vancomycin resistant in CoNS [11].

Our result shows that highest resistance to vancomycin was reported in thirteen years old girl with renal failure isolates no [p11] with MIC of vancomycin is $64 \mu \mathrm{g} / \mathrm{ml}$ with recurrent hospital admission with last one was more than 10 days with history of vancomycin use and it was positive to van A gene and mec gene.

All VRSA isolates had mec gene and the patient had history of recurrent hospital admission with last one was more than five days with history of vancomycin use. The data of the VISA and VRSA is shown in Table 2 in relation to the detection of mec gene and van gene and clinical history.

The mechanism of transmission of hospital acquired resistance strain could be by many ways from patients or health care worker as well as from the environmental surfaces, while the transmission of coagulase- negative staphylococci is not fully known but it's probably the same rout of transmission [20]. Also the duration of hospital stay and history of glycopeptides antibiotics and to some extent the causes of underlying diseases as renal failure appear to be significant risk factor in increasing the resistance [22].

Vancomycin resistance in $S$. aureus mechanism is not known it would be that $S$. aureus acquire (Van gene) vancomycin resistance gene [15]. The result of multiplex pcr in this study shows that vancomycin resistance gene were not present in all isolates. But the absence of vanA/B genes in the isolates dose not rule out that these strains are not VRSA or VISA as there is another hypothesis which stat that cell wall thickening is play role in vancomycin resistance. Biochemical and transmission electron microscopy (TEM) examination of the Mu50 cell, show that increased of peptidoglycan. More murein monomers and more layers (probably 30-40 layers as judged by cell-wall thickness observed with TEM) of peptidoglycan are to be present in the cell wall. As a result, more vancomycin molecules are trapped in the peptidoglycan layers before reaching the cytoplasmic membrane where peptidoglycan synthesis occurs [21].

The widespread of vancomycin resistance in hospitals lead to focusing on infection control role in emerging of vancomycin-resistant staphylococci. In our study the Hospital Infection Control Practices Advisory Committee (HICPAC) of the infection control guidelines for staphylococci resistance was followed To detect how it was implemented and its role in spreading the resistance strains. In Table 3 how much implantation of infection control practices was checked in two CONS with intermediates resistance to vancomycin and in Staphylococcus aureus with VRSA. It was reported that not all the items were implemented in our hospital this strong risk factor to increases the rate of resistance isolates.

\section{Conclusion}

Our study shows the magnitude of VRSA or VISA in hospital acquired infection and a strict regulation on use of antibiotics with implementation of infection control policy is the effective way that we could do to prevent the spread of the resistance strain.

\section{Funding}

This work was not supported by any financial funding.

\section{Conflict of Interest}

The authors declare that they have no conflict of interest.

\section{Ethical Approval}

All procedures performed in this study involving human participants 
Citation: Zaki MES, Abouelnour A, El-Kannishy SMH, Hassan R (2019) Molecular Study of Vancomycin Resistance in Hospital Acquired Staphylococcus Infection. Int J Drug Dev \& Res 11: 11-14

were in accordance with the ethical standards of Mansoura Faculty of Medicine ethical committee.

\section{Informed Consent}

Informed consent was obtained from all individual participants included in the study

\section{References}

1. Demetrio LV, Phyllis Anne P, Esperanza C, Windell LR (2016) Molecular and phenotypic characterization of methicillin-resistant Staphylococcus aureus isolates from a tertiary hospital in the Philippines. Tropical Medicine and Health $44: 3$

2. Catherine L (2011) Clinical Practice Guidelines by the Infectious Diseases Society of America for the Treatment of Methicillin-Resistant Staphylococcus aureus Infections in adults and children. Clinical Infectious Diseases. 52: 18-55.

3. Van Cleef BA, Monnet DL, Voss A (2011) Livestock-associated methicillin-e resistant Staphylococcus aureus in humans, Europe. Emerg Infect Dis 17: 502

4. Jungk J, Como-Sabetti K, Stinchfield P, Ackerman P, Harriman K, et al. (2007) Epidemiology of methicillin-resistant Staphylococcus aureus at a pediatric healthcare system, 1991-2003. Pediatr Infect Dis J 26: 339-344.

5. Tenover FC, Moellering RC (2007) The rationale for revising the Clinical and Laboratory Standards Institute vancomycin minimal inhibitory concentration interpretive criteria for Staphylococcus aureus. Clin Infect Dis. 44(9): 12081215.

6. Pérez-Roth E, Claverie-Martín F, Batista N, Moreno A, Méndez-Álvares S, et al. (2002) Mupirocin resistance in methicillin resistant Staphylococcus aureus clinical isolates in a Spanish hospital. Co-application of multiplex PCR assay and conventional microbiology methods. Diag Microbiol Infect Dis 43:123-128.

7. Donabedian S, Hershberger E, Thal LA, Chow JW, Clewell DB (2000) PCR fragment length polymorphism analysis of Vancomycin-resistant Enterococcus faecium. J Clin Microbiol 38: 2885-2888.

8. Clark N C, Cooksey RC, Hill BC, Swenson JM, Tenover FC (1993) Characterization of glycopeptide-resistant enterococci from U.S. hospitals. Antimicrob Agents Chemother 37: 2311-2317.

9. Michel A, Richard Q (2001) Regulation of Van A and Van B type glycopeptides resistance in Enterococci. ACC 45: 375-387.
10. Whitener CJ (2004) Vancomycin-resistant Staphylococcus aureus in the absence of vancomycin exposure. Clin Infect Dis 38: 1049-1055.

11. El Kholy A, Baseem H, Hall GS, Procop GW, Longworth DL (2003) Antimicrobia resistance in Cairo, Egypt 1999-2000: a survey of five hospitals. J of Ant Chem 51: $625-630$.

12. Ahmed SH, Daef EA, Badary MS, Mahmoud MA, Abd-Elsayed AA, et al. (2009) Nosocomial blood stream infection in intensive care units at Assiut University Hospitals (Upper Egypt) with special reference to extended spectrum $\beta$-lactamase producing organisms. BMC Research Notes 2: 15-19.

13. Hadler JL, Petit S, Mandour M, Cartter ML (2012) Trends in invasive infection with methicillin resistant Staphylococcus aureus, Connecticut, USA, 20012010. Emerging Infectious Diseases 18 (6): 917-924

14. Saderi H, Owlia P, Nadoushan MRJ (2009) Difference in epidemiology and antibiotic susceptibility of methicillin resistant and methicillin susceptible Staphylococcus aureus isolates. Iranian Journal of Clinical Infectious Diseases 4 (4): 219-223

15. Limbago B, Kallen AJ, Zhu W, Eggers P, McDougal LK, et al. (2014). Report of the $13^{\text {th }}$ vancomycin-resistant Staphylococcus aureus isolate from the United States. J Clin Microbiol 52: 998-1002.

16. Bataineh AB (2006) Resistance of Staphylococcus aureus to vancomycin in Zarqa, Jordan. Pak J Med Sci 22: 144148.

17. Clinical and Laboratory Standards Institute (2015) Performance Standards for Antimicrobial Susceptibility Testing. Twenty-Fifth Informational Supplement M100-S25. Wayne, PA: CLSI.

18. Saadat S, Solhjoo K, Norooz Nejad J, Kaze A (2014) Van A and Van B positive vancomycin-resistant Staphylococcus aureus among clinical isolates in Shiraz, South of Iran. Oman Medical Journal 29(5): 335-339.

19. Gardete S, Tomasz P (2014) Mechanisms of vancomycin resistance in Staphylococcus aureus. J Clin Invest. 124(7): 2836-2840

20. Zeng J, Hu Y, Jia T, Zhang R, Su T, et al. (2018) Chemo enzymatic synthesis of sialylated lactuloses and their inhibitory effects on Staphylococcus aureus. 13: $199-334$.

21. Mc Guinness WA, Malachowa N, De Leo FR. Yale J (2017) Vancomycin resistance in Staphylococcus aureus Jun 90: 269-281.

22. Pina PC, Marliere F, Vandenesch JP, Bedos J, Etienne P, et al. (2000) An outbreak of Staphylococcus aureus strains with reduced susceptibility to glycopeptides in a French General Hospital. Clin Infect Dis 31:1306-1308. 